\title{
Building library leadership in Africa: A proposed education initiative
}

\author{
Johannes J. Britz ${ }^{\text {a, b}}$, Peter J. Lor ${ }^{\mathrm{c}}$ and Theo J. Bothma ${ }^{\mathrm{d}}$ \\ ${ }^{a}$ School of Information Studies, University of Wisconsin-Milwaukee, Milwaukee, WI, \\ USA \\ ${ }^{b}$ Department of Information Science, University of Pretoria, Pretoria, South Africa \\ ${ }^{\mathrm{C}}$ Department of Information Science, International Federation of Libraries and \\ Institutions (IFLA), University of Pretoria, Pretoria, South Africa \\ ${ }^{\mathrm{d}}$ Department of Information Science, University of Pretoria, Pretoria, South Africa
}

\section{Summary}

This article deals with a proposed initiative to train library managers on the African continent. It is argued that such an education initiative will contribute to the socioeconomic development of Africa. Issues addressed in the article include the following: the background to and rationale for this initiative, justification for the University of Pretoria to be the degree-issuing institution, the delivery mode, outline of the proposed curriculum and expected outcomes of this initiative.

\section{Article Outline}

Introduction

Background to and rationale for this initiative

Detail of proposal

Degree-issuing institution

Quality

Relevancy and context

Cost factor 


\author{
Brain drain \\ Delivery mode \\ Student selection \\ Faculty members \\ Outline of the curriculum \\ Expected outcomes of the project \\ Long term outcomes \\ Other related outcomes \\ Conclusion \\ References
}

\title{
Introduction
}

The School of Information Studies at the University of Wisconsin-Milwaukee (USA), in collaboration with the Department of Information Science at the University of Pretoria (South Africa) took the initiative to get directly involved in the education of information professionals in Africa. We invited several other leading experts, representing educational institutions as well as organizations around the world to join our venture. These include experts from Emporia State University (USA), University of South Carolina Upstate (USA), and Wayne State University (USA).

As initiators of this project, we share the conviction of the G8 countries, the World Bank, the United Nations and other influential role-players that poverty and stagnation in Africa is the greatest tragedy of our time and that it demands a forceful response (G8 Report on Africa, 2005; United Nations University, 1998; World Bank, 2000). We strongly agree with Paul Wolfowitz, the current president of the World Bank, that we have a "moral obligation” to assist Africa (Economist, 2005).

It is our belief that one the most important responses is to invest in the people of Africa in Africa —not only in terms of primary education, but more specifically in higher education and R\&D. The G8 Report on Africa states: "Investing for economic growth means 
rebuilding African health and educational systems, many of which are now on the point of collapse (2005, p. 15).”

It is furthermore our conviction that libraries and other information services play a crucial role in the social and economic development of all countries on the African continent. It goes without saying that libraries and other information services have played a vital role in developed countries. These countries have benefited from sophisticated information and library infrastructures that provide information to people in the public and private sectors. Our initiative is, therefore, aimed at giving Africa the advantage of high-quality library and information services, by investing in high-quality education of African library and information workers. The direct benefit of this initiative is that graduates from this program will have a high degree of ownership of their own future skills development and the ability to create new knowledge, enabling them to keep pace with the constant changes in technological developments and to train newcomers in their own cadres.

We, therefore, proposed this initiative to

- identify and select 15 students of very high potential in Library and Information Science in Africa,

- offer them the opportunity to enroll in a Masters degree program in Information Science at one of the top universities in Africa (the University of Pretoria), and

- expose them to the leading international experts in this field.

Background to and rationale for this initiative

This proposal is based on the following core assumptions:

- Education is a fundamental human right and a common good that benefits all.

- Library and Information Science education is instrumental to human development and critical to economic growth and quality of life on the African continent.

Two of the authors (Britz \& Lor) recently completed an in-depth research project on Africa as a knowledge society as well as the role that libraries in Africa can play to combat information poverty on the continent (Britz, Lor, Coetzee, \& Bester, 2006; Britz $\&$ Lor, 2007). Some of the major findings relevant to this project are: 
- Education is the primary and long-term solution to address poverty in Africa and to ensure sustainable development.

- Investment in Research and Development, as well as in Higher Education, is the key to knowledge generation, innovation, and wealth creation.

- Africa's higher education is in a state of crisis.

- The development of curricula relevant to Africa and its needs is sorely lacking.

- There is an alarming and persistent brain drain of professionals from Africa.

- There is an urgent need for the training of information professionals to manage information and data to promote efficient decision making. We quote the Commission for Africa Report (2005, p. 154), “One thing that has emerged from all our considerations on issues of governance and capacity is the importance of good information and communication.”

- Management skills are in short supply among information professionals at the management level. This severely hampers the effective management of libraries and information centers in terms of the information itself, the infrastructure and human resources. Remedying this shortfall will ensure proper, equitable and sustainable access and use of information.

What further motivated the initiation of this project is our conviction that managers of libraries in Africa need a change of mindset. Lor (2000) argued that in the African context, we have to deal quite often with demoralized library managers. Their libraries are severely under funded, their purchases of library resources are woefully inadequate, they lack trained staff, their technology, is in many cases, out of date, and their connectivity is poor. They are, therefore, unable to perform according to what is expected of them, and recognition of their efforts is lacking. For some, it seems that they are in a downward spiral: inadequate resources, hence poor service, hence lack of recognition, and hence inadequate resources. After beating their heads against a wall for years, these managers resign themselves to their situation. Passivity and negativity set in. They do not make things happen. Things (mostly bad) happen to them. The bright ideas of younger staff are in many cases squashed because the library manager has seen it all before and knows from experience that "it will not work." The big challenge in improving libraries 
in Africa lies indeed in changing the mindset of the librarians, especially that of the library managers.

Our proposal for this higher education initiative furthermore ties in with the 10 years partnership program, "Renewing the Universities," agreed upon in 2003 between the African Association of Universities (AAU), the South African Association of Vice Chancellors and the Association of Commonwealth Universities (ACU). Two of the main objectives of this program are:

- "To encourage the development of partnerships between universities and the corporate sector to promote the development of both urgently needed specific skills and entrepreneurship," and

- "To increase significantly the participation of African universities in the global knowledge economy and to promote North/South and South/South collaboration, not least through the development and inclusion of internationalism in all aspects of the curriculum (Renewing the African University, 2003, p. 1).”

\section{Detail of proposal}

\section{Degree-issuing institution}

The University of Pretoria (UP) in South Africa, through its Department of Information Science within the School of Information Technology, will be the degree-issuing institution. We specifically chose an African based university because of the need for relevant and contextual education of library managers in Africa. It is also our hope that issuing of an African-based degree will combat the current brain drain of professional labour. The cost-factor can also not be ignored. The tuition fees at American state universities are much higher than at their counter institutions on the African continent. The criteria we used for selecting an appropriate LIS school in an African university are as follows:

- Excellent record of research and scholarship (articles \& books published).

- Large staff with good range of expertize within the school/department.

- Located in a university/school with further range of expertize available. 
- Located in a city or region with a range of excellent libraries and information services and experienced and visionary library leaders.

- Located on a campus and in a city with excellent communication links to other African countries.

The Department of Information Science within the School of Information Technology, at the University of Pretoria meets most of the set criteria.

\section{Quality}

The UP is one of the outstanding universities in Africa and has a very good national as well as international reputation and standing. Furthermore, the Department of Information Science was evaluated in 2000 by external reviewers as one of the top schools in the world. The University of Pretoria has also been the leading university in South Africa in terms of production of research articles accredited by the Department of Education in South Africa. The University uses the Institute for Scientific Information (ISI) citation and publications index to benchmark its research quality and performance (UP Research, 2004).

\section{Relevancy and context}

By selecting the University of Pretoria as an African-based university, we ensure that the course content is applicable to the specific needs of Africa. This view is supported by the African Union as well as NEPAD (New Economic Partnership for African Development) who expressed a clear desire that Africans be educated in Africa. We quote from the document, Renewing the African University (2003, p. 1), "We share the belief that universities of Africa must be at the heart of any sustainable effort to rebuild the continent.”

\section{Cost factor}

Tuition at UP is on average about 10 times cheaper than the equivalent at state universities in the United States (US). The tuition fee for a Masters-degree student at UP is approximately $\$ 4500$ for two years. The equivalent Masters degree in Library and 
Information Science (MLIS-36 credits) at the University of Wisconsin-Milwaukee would be approximately $\$ 46,000$ per student paying out-of-state non-resident graduate tuition (UWM, 2006).

\section{Brain drain}

Recent statistics are proof of the fact that most African scholars who graduate at American and European institutions do not return to work in Africa (Britz et al., 2006). The Commission for Africa Report (2005) estimates that more African scientists and engineers are working in the USA than in the whole of Africa. By issuing a quality African-based degree, we hope to contribute to current "brain gain” initiatives aiming to reverse the brain drain in Africa. Some of these initiatives include the TOTKEN project (Transfer of Knowledge through Expatriate Networks) run by the United Nations Development Program as well as the South African Network of Skills Abroad program (SANSA) (S.A. National Research Foundation, 2002).

\section{Delivery mode}

This will be a hybrid course using the WebCT course management platform. In conjunction with online teaching, students will have on-campus exchanges together with faculty during each of the four semesters. Each of the exchanges will be for ten days. The meetings are scheduled as follows:

\begin{tabular}{|l|l|}
\hline When? & Which Campus? \\
\hline First semester & University of Pretoria \\
\hline Second semester & University of Wisconsin-Milwaukee \\
\hline Third semester & University of South Carolina Upstate \\
\hline Fourth semester & University of Pretoria \\
\hline
\end{tabular}

When the students attend at the designated onsite sessions scheduled at the above venues, they will also visit other sites and institutions that are important to their education, for 
example, the Library of Congress in Washington DC, and the National Library in Pretoria, South Africa. Guest lecturers will also be invited to do presentations on specific topics. Likewise, students will have the opportunity to do guest lectures as well. This will ensure the generation of a needed confrontation between the theory that the students learn and the situations to which they return after the sessions at UP, UWM, and USCU.

\section{Student selection}

The aim is to select only the most promising students from all of Africa who meet the standards and criteria to enroll in the Masters program at the University of Pretoria. Strong preference will be given to students who have practical experience at least at middle management level in their libraries/information organizations, and who have the possibility to disseminate their gained knowledge effectively. Recruitment will also focus on those areas in sub-Saharan Africa where there is either inadequate access or a lack of higher education facilities. These include amongst others Mozambique, Zimbabwe, Angola, Lesotho and Swaziland.

\section{Faculty members}

Faculty members are carefully selected based on the following criteria:

- international academic standing in their field of expertize,

- specific knowledge and skills required in terms of the curriculum,

- the ability to contextualize content within the African context and also to give the students a broader international perspective of how to manage and conduct the generation of new knowledge.

\section{Outline of the curriculum}

Library leaders need a sound grasp of management, so we start in Module 1, "Management concepts and techniques for library leaders," with a review of basic management principles and concepts before proceeding to concepts of strategic planning and decision-making and the management of strategic resources (finance, human resources, ICTs, etc.) in the context of a LIS organization, not neglecting measurement and evaluation. The second module, "Leadership in libraries and information 
organizations,” deals with leadership as distinct from management. Various dimensions of leadership are explored, including the ethical, emotional and hygienic. This module also gives considerable weight to leadership within the institutional contexts of course participants, who will be required to do a detailed and systematic study of their respective institutional settings as part of Module 2. We expect library leaders to have the capacity and skills to be able to communicate with other leaders in their organizations and want them to be able to rise to the position of Chief Information Officer in their universities, cities or institutes. To take a university setting as an example, no university library director can be an effective member of the leadership team of his or her university if he or she does not have a sound grasp of what is happening in the technologies that are transforming education and scholarly work, not to forget developments in the broader policy and legal environment, such as those relating to intellectual property. Hence Module 3 covers "E-trends in the Library and Information Business.” A leader should have a wide, strategic vision and be able to relate his or her organizational challenges to the more global situation, with particular reference in this case to Africa. This is covered in Module 4, "Global perspectives on the information and knowledge society,” which covers such themes as globalization, the African renaissance and information relations between South and North. The final module, "Knowledge management” reflects the strategic value of knowledge in society and organizations and seeks to equip the library leader with the knowledge and skills needed to situate the library activities in the wider context of the institution's knowledge resources.

\section{Expected outcomes of the project}

\section{Long term outcomes}

The most important outcome of this project is that it will contribute to Africa's knowledge base. It is an investment in higher education that will allow the creation of new knowledge, innovation, and roll over into the training of others. This outcome is directly in line with the vision of NEPAD, which is to invest more in higher education and R\&D on the continent. This ability allows Africa to enter and participate in the global knowledge economy. 
On a reciprocal basis, international faculty members involved in the teaching will have the opportunity to learn from the African students and their experiences. The gained knowledge can then be ploughed back into their respective institutions in terms of both research and teaching.

\section{Other related outcomes}

- Provide 50 master's graduates in library and information management by the year 2010 in those countries on the African continent with the greatest need.

- Involve five different institutions and three countries in a unique educational program that can be replicated in other countries and institutions.

- Africa will gain specialized skills and expertize to process, distribute and manage cutting-edge technologies with their own wealth of knowledge.

- These graduates will have a high degree of ownership of their own future skill development, enabled to keep pace with the constant changes in technology and to train newcomers in their own cadres.

- The students will make public their research findings at an international conference. The overarching topic of their research will be: investing in the future of Africa.

- Their research findings will be submitted for publication to internationally peerreviewed journals.

\section{Conclusion}

In this article we have argued that one of the most important responses to the current socio-economic crises in Africa is to invest in the people of Africa in Africa-not only in terms of primary education, but more specifically in higher education and R\&D.

It is also our conviction, based on the evidence of the pivotal role that libraries played in the development of industrialized countries, that libraries and other information services can and must play a crucial role in the social, political, as well as economic development of all countries on the African continent. We have argued in this article that this education initiative will be aimed at giving Africa the advantage of high-quality library and information services by investing in high-quality education of African library and information managers. We are also convinced that the direct benefit of this initiative will 
be that graduates from this program will have a high degree of ownership of their own future skills development and the ability to create new knowledge, enabling them to keep pace with the constant changes in technological developments and to train newcomers in their own cadres. This will ensure the sustainability of this initiative and will ensure that libraries and other information services will take their rightful leadership role in the development of Africa.

\section{References}

Britz, Lor, Coetzee, \& Bester (2006) Johannes J. Britz, Peter J. Lor, Elsabe M. Coetzee and Ben C. Bester, Africa as a knowledge society: A reality check, The International Information and Library Review 38 (1) (2006), pp. 25-40.

Britz, Johannes, Lor, \& Peter Britz, Johannes J., and Lor, Peter J. Is a knowledge society possible without access to information? Journal of Information Science, Retrieved March 29, 2007 from http://jis.sagepub.com/cgi/rapidpdf/0165551506075327v1). Commission for Africa Report (2005) Commission for Africa Report. (2005). Renewing the universities: commission for Africa supports ACU/AAU Partnership. Retrieved September 5, 2006 from (http://www.acu.ac.uk/cgi-bin/pressrelease.pl?PRID=30\% . G8 Report on Africa (2005) G8 Report on Africa. (2005). G8 Gleneagles 2005: policy issues. Retrieved September 19, 2005 from \ http://www.g8.gov.uk/servlet/Front?pagename=OpenMarket/Xcelerate/Showpage\&c+Pa ge.

Lor (2000) Peter J. Lor, Libraries in the African Renaissance: African experience and prospects for survival in the information age, International Information and Library Review 32 (2) (2000), pp. 213-236.

Renewing the African University (2003) Renewing the African University. (2003). A ten year partnership of the Association of Commonwealth Universities, the South African Association Vice Chancellors and the Association of African Universities. Retrieved September 5, 2006 from http://www.aau.org/gc11/adocs/pdf/eng/aau-acusauvcaprog.pdf $\rangle$. 
National Research Foundation (2002) S.A. National Research Foundation. (2002).

SANSA: South African network of skills abroad. Retrieved September 1, 2002 from http://sansa.nrf.ac.za/interface/AboutSANSA.htm $/$.

Research (2004) UP Research. (2004). University of Pretoria: 2004 research. Retrieved September 5, 2006 from /http://www.research.up.ac.za/2004 $/$.

Economist (2005) Economist, The $\$ 25$ billion question—Aid to Africa: Special report, The Economist 376 (8433) (2005), p. 25.

United Nations University (1998) United Nations University. (1998). United Nation

University: higher education and knowledge. Retrieved October 17, 2005 from \ http://www.unu.edu/africa/00sps-strengthen.html $/$.

UWM (2006) UWM. (2006). Tuition and fee rate Fall 2006. Retrieved September 5, 2006 from http://www.bfs.uwm.edu/fees/Fall2006/TuitionSchedule.htm $\%$.

World Bank (2000) World Bank, Can Africa claim the 21st century? World Bank Report, The World Bank, Washington, DC (2000). 